\title{
喉頭レベルでの気道確保術としての輪状軟骨開空術
}

\author{
鹿野真人 ${ }^{1)} \cdot$ 高取隆 ${ }^{1)} \cdot$ 小針健 大 $^{1)}$ \\ 佐 藤 廣 仁 $^{1)} \cdot$ 木田 雅 彦 ${ }^{2)}$
}

\section{Cricoid Fenestration : A Novel Surgical Airway-opening Technique at the Larynx using Partial Resection of the Cricoid Cartilage}

\author{
Makoto Kano ${ }^{1)}$, Takashi Takatori $^{1)}$, Takehiro Kobari ${ }^{11}$ \\ Hirohito Satoh ${ }^{1)}$ and Masahiko Kida ${ }^{2)}$
}

In 2007, we reported a newly-developed surgical airway-opening technique (cricoid fenestration) using a partial resection of the cricoid cartilage to form a stoma. From 2006 to 2014, a total of 57 cricoid fenestration procedures were performed at our hospital. The reasons for surgery included cervical disturbances such as low-set larynx, obesity, short neck, thyroid tumor, cervical abscess, and tortuous brachiocephalic and common carotid artery. Surgeries were also performed in high-risk patients who required long-term airway management, hemostasis, and urgent airway establishment. In this study, only one patient developed subcutaneous emphysema as an intra- or postoperative complication.

Cricoid fenestration enables us to easily create a stoma at a higher level of the cricoid cartilage without transecting the thyroid gland. In addition, this technique can quickly establish a controlled airway with a low risk of intraoperative bleeding. Finally, long-term airway management can be performed easily using this technique without tube-related complications including scarring or stenosis, despite the resection of the cricoid cartilage. Cricoid fenestration is therefore considered to be a safe and effective surgical airway-opening technique.

Key words : tracheostomy, partial resection of cricoid cartilage, complication, surgical airway-opening technique

\section{は じめに}

外科的な気道確保術として, 通常の気管切開術や, 超緊 急時には輪状甲状靯帯穿刺・切開術が選択される。一方, 肥満・短頸, 喉頭低位, 頸部伸展不良や気管切開部での甲 状腺腫大 ·腫瘍, 腕頭 - 総頸動脈蛇行症など頸部の異常, さらに近年では抗血栓剤の内服により出血傾向を有する症 例に遭遇し，気道確保術に難渋することも少なくない，ま た、高齢化社会と共に, 虚弱・寝たきり患者の増加に伴い, 長期気道管理を要する症例に対する気管切開術の依頼も増 し，その結果，長期気管カニューレ留置に起因する肉芽・ 狭窄などの晚期合併症が問題となる症例も多い。こうした 術中・術後の合併症の対策として従来の外科的な気道確保 術で対処するには限界があり，ハイリスク症例に対して新 たな選択肢となる安全な気道確保術が望まれる。

われわれは，甲状腺・気管を切開せず輪状軟骨を鉗除し 喉頭レベルに気道確保する術式 (以下,「輪状軟骨開空術」 と称する）を 2007 年から報告してきた ${ }^{1,2)}$ 。その後, 他の 施設からも本術式での治療経験が報告されている ${ }^{3 \sim 6)}$ 。輪 状軟骨を操作することは一般に禁忌として認識されてきた
が, 輪状軟骨の位置での気道確保は頸部の形態や気管切開 部の問題に左右されずに切開孔を形成できること,ささらに 皮膚から気道まで最短距離で到達できることから，ハイリ スク症例に対して有用な術式になることが推察される.

今回，重ねてきた症例の経験から，輪状軟骨鉗除の安全 性とともに本術式の利点と適応を検討し，ハイリスク症例 での早期・晚期合併症回避を目的とした，新しい気道確保 術の選択肢としての可能性や適切な選択のためのフロー チャートについて考察したので報告する.

$$
\text { 術式 }
$$

輪状軟骨開空術の術式の詳細を述べる（図 1)。皮膚切開 は輪状軟骨上の縦切開とする。前頸筋正中の白線を切離、 輪状甲状筋が付着する輪状軟骨を触知し明視下にする。筋 を軟骨から剥離し前方の軟骨を露出する，軟骨をリウエル 型丸のみ鉗子にて鉗除し, 現れた甲状軟骨と第 1 気管輪と の間の膜を切開し声門下腔に到達する。横 $\mathrm{H} に$ 切開された 膜を皮虐と縫合し切開孔を形成する。甲状腺峡部には操作 を加えないが、輪状軟骨を覆う錐体葉がある場合には切離 しておく

1) 大原綜合病院耳鼻咽喉科頭頸部顔面外科

2) 福島寿光会病院

1) Department of Otolaryngology Head and Neck Maxillofacial Surgery, Ohara General Hospital

2) Fukushima Jukoukai Hospital 


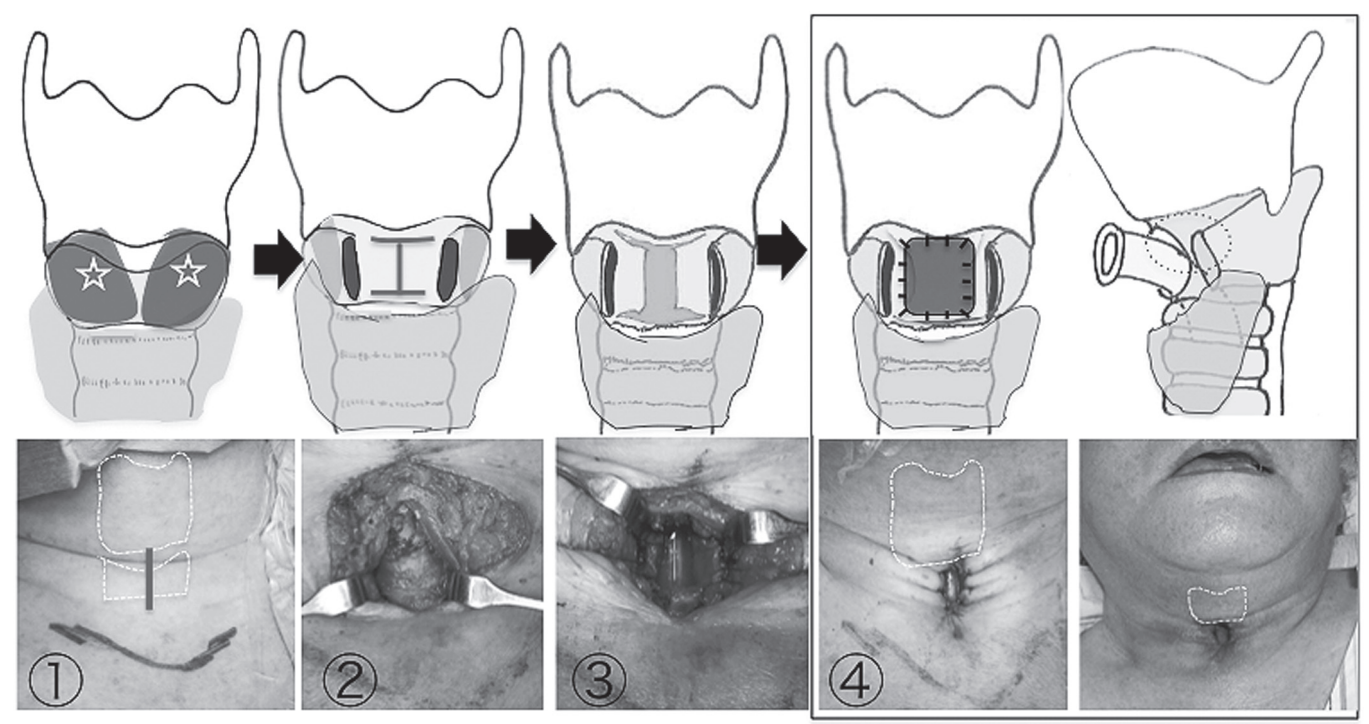

図 1 輪状軟骨開空術の術式

(1)：輪状軟骨の高さに皮膚切開。云：輪状甲状筋

(2) : 軟骨輪状軟骨の前方を鉗除。甲状腺には操作を加えない.

(3)：軟骨膜を横 $\mathrm{H}$ に切開。(4)：軟骨膜と皮膚を䋮合.
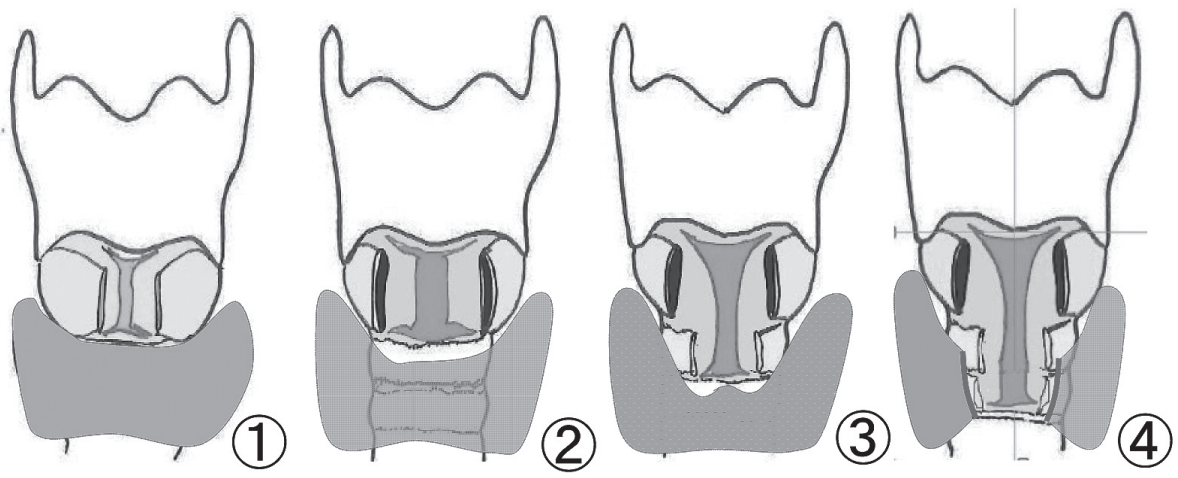

図 2 輪状軟骨開空術のバリエーション
(1)：輪状軟骨を最小限に鉗除。(2)：軟骨を最大限に鉗除.
(3): 輪状軟骨鉗除と第 1 気管輪切開.
(4): 輪状軟骨鉗除と第 1,2 気管輪切開, 甲状腺峡部切断.

形成する切開孔の大きさを調整するためのバリエーショ ンを示す (図 2). 術後早期に切開孔を閉鎖する症例では輪 状軟骨の鉗除を最小限にする。一方、長期の切開孔開存を 目的とする症例では輪状軟骨を可及的に大きく鉗除する が、第 1 気管輪にも切開を加えて拡大する術式や，甲状腺 峡部を離断し第 $1 ， 2$ 気管輪を切開することで，より確実 な開存を目的とする術式も選択可能である.

$$
\text { 対 }
$$

象

2006 年 1 月から平成 2014 年 12 月まで, 当科で行われ た気道確保術は 140 例であった。 その術式の内訳をみると， 気管切開術：80 例 (中気管切開術 77 例, 上気管切開術 3 例), 輪状甲状靯帯穿刺術：3 例であったが, 本報告の対象
となる輪状軟骨開空術は 57 例であった。 57 例の性別は男 性 34 例、女性 23 例。平均年齢は 74.3 歳であった。 57 例 中、輪状軟骨の単独鉗除が 31 例, 輪状軟骨に加えて第 1 気管輪も切開した症例が 21 例，輪状軟骨に第 $1 ， 2$ 気管輪 を切開した症例が 4 例であった。輪状軟骨とともに切開上 縁の甲状軟骨下縁の一部を鉗除した症例が 1 例あった。

結

果

\section{1. 輪状軟骨開空術の選択理由}

輪状軟骨開空術 57 例の術式選択の理由をまとめた（表 1). 両側反回神経麻痺など不可逆的な気道狭窄や吸痰処置 のため長期の切開孔管理が必要と判断され，切開孔閉鎖を 予定しなかった症例は 41 例あり, 平均年齢 79.9 才で半数 
表 1 輪状軟骨開空術 57 例の選択理由

\begin{tabular}{|c|c|c|c|c|c|}
\hline 長期切開孔管理 & 41 & 頭頸部癌末期 & 10 & 上気道狭窄 & 6 \\
\hline 長期気管孔管理のみ & 9 & 頸部放射線治療：口腔癌 & 4 & 頸部膿瘍 & 1 \\
\hline 喉頭低位 & 9 & 頸部放射線治療：喉頭·下咽頭癌 & 3 & 頸部皮下出血・喉頭出血 & 1 \\
\hline + 頸部伸展困難 & 2 & 甲状腺未分化癌 & 1 & 肥満・短頸 (喉頭蓋炎) & 1 \\
\hline + 抗血栓剂 & 2 & 食道癌・甲状腺浸潤 & 1 & 喉頭低位 (超緊急) & 1 \\
\hline + CPAP使用 & 1 & 涙需癌 & 1 & 抗血栓剤・高齢 (急性喉頭蓋炎) & 1 \\
\hline + 短頸 & 1 & & & 頸椎術後・頸部伸展不能 & 1 \\
\hline 肥満・短頸 & 3 & & & & \\
\hline 腕頭・総頸動脈蛇行症 & 1 & & & & \\
\hline ＋頸部伸展困難 & 1 & & & & \\
\hline+ 短頸 & 1 & & & & \\
\hline 多動・不穏 & 2 & & & & \\
\hline 十肥満＋カニューレフリー & 1 & & & & \\
\hline 出血傾向 & 1 & & & & \\
\hline + 自己抜去リスク & 1 & & & & \\
\hline CPAP使用 & 2 & & & & \\
\hline カニューレフリー & 1 & & & & \\
\hline 全身状態不良 & 1 & & & & \\
\hline 甲状腺腫瘍 & 1 & & & & \\
\hline 超緊急 + 頸部伸展困難 & 1 & & & & \\
\hline
\end{tabular}
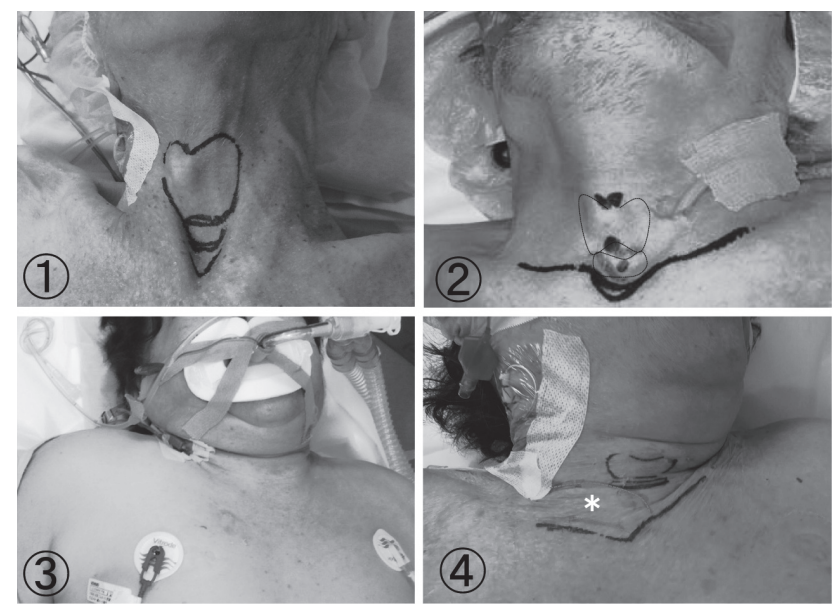

図 3 輪状軟骨開密術適応の頸部異常症例
(1)：喉頭下垂による喉頭低位.
(2)：頸部拘縮と喉頭低位
(3)：肥満・短頸.
(4): 腕頭動脈蛇行症と短頸. (* : 腕頭動脈)

以上の 22 例が 80 才以上であった。 この 41 例に本術式を 選択した理由は長期管理のみであったものが 9 例，一方， 長期管理に加えて，喉頭低位があり選択したものが 9 例あ り、さらに頸部拘縮による伸展困難、抗血栓剂使用, $\mathrm{CPAP}$ 使用や短頸など複数の理由を有するものが 6 例あっ

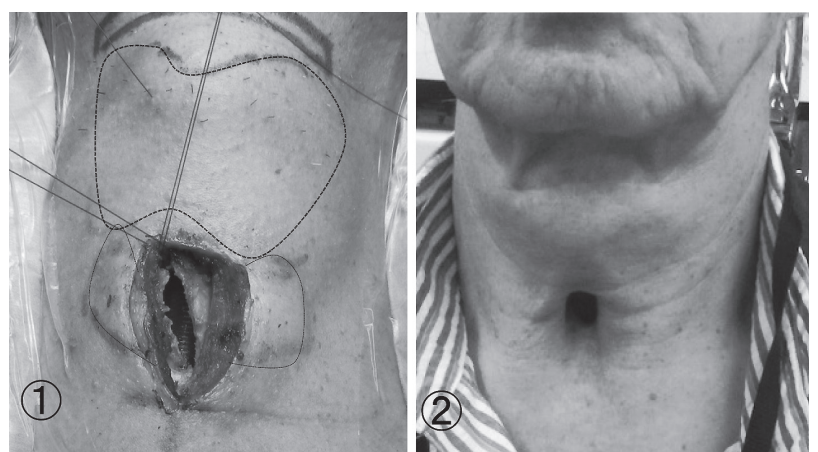

図 4 気管カニューレフリーの切開孔

(1)：輪状軟骨前方を広範に鉗除し第一気管輪も切開.

(2)：4 年後の切開孔. 気管カニューレなしでも開存.

た（図 3-1)，(2)）。肥満・短頸が 3 例（図 3-(3)）、腕頭動脈 や総頸動脈の蛇行症は短頸や頸部伸展困難を合併する症例 も含めて 3 例（図 3-(4)）であった。また多動・不穏が理由 であったのが 3 例，CPAP使用目的は 2 例，出血傾向は $\mathrm{DIC}$ 症例と抗血栓剤内服中でカニューレ自己抜去のリスク を有する例の 2 例であった。 カニューレフリーの管理目的 （図 4)、全身状態不良、甲状腺腫瘍や超緊急性がそれぞれ 1 例であった。

頭頸部癌末期の上気道狭窄症例は 10 例あり, 緩和治療 として閉鎖を目的としない気道確保術として選択された。 

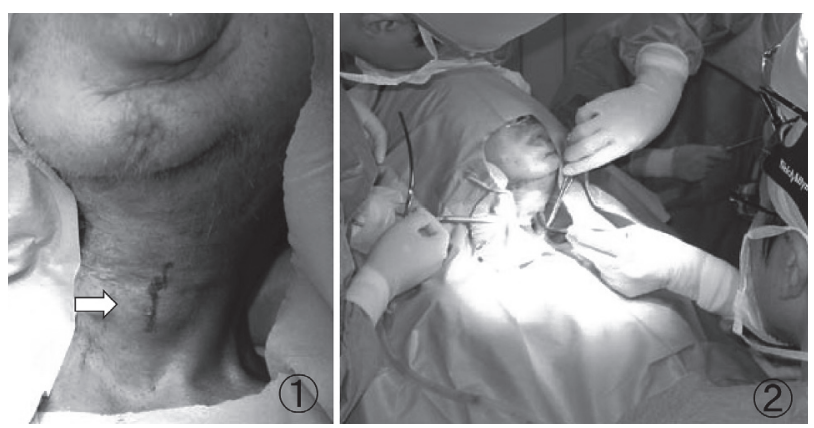

図 5 放射線治療後の上気道狭窄症例

(1)：放射線治療後で硬く拘縮している頸部.

輪状軟骨のみが触知 $(\rightarrow)$

(2)：臥位ができず，座位にて輪状軟骨開空術を行った
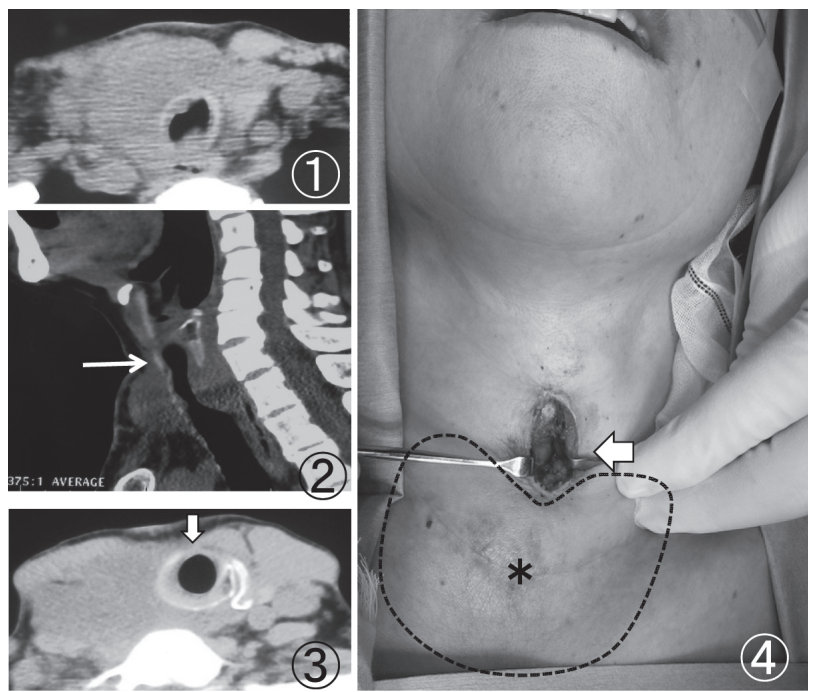

図 6 甲状腺未分化癌症例での輪状軟骨開空術

(1) : 甲状腺峡部の腫瘍像.

(2)：峡部腫瘍と輪状軟骨 $(\rightarrow)$ との位置関係.

(3): 輪状軟骨開空術の気道への到達経路.

(4): 甲状腺右葉と峡部の腫瘍 $(*)$ ため輪状軟骨を鉗除 して気道に到達.

術後ないしは根治放射線治療が行われた症例は 10 例中 7 例あり，それぞれ口腔癌 4 例，喉頭・下咽頭癌 3 例であっ た。うち口腔底癌再発の 1 例は頸部拘縮のうえ逼迫した超 緊急切開のため半座位で行った(図 5). 甲状腺未分化癌(図 $6)$, 食道癌の甲状腺浸潤と涙囊癌の各 1 例は未照射例で あった。

上気道狭窄により緊急の気道確保が必要とされたものが 6 例あったが、通常の気管切開術では合併症が危惧された 症例であった，選択理由は前頸部の広範な膿瘍（図 7) や 抗血栓剂内服中の喉頭から頸部に及ぶ広範な皮下血腫など 気管切開部の問題，また，喉頭蓋炎の肥満・短頸例，気管 挿管不能で超緊急の喉頭低位の下咽頭放射線治療例などの 頸部の異常, さらに抗血栓剂内服中の高齢者の急性喉頭蓋
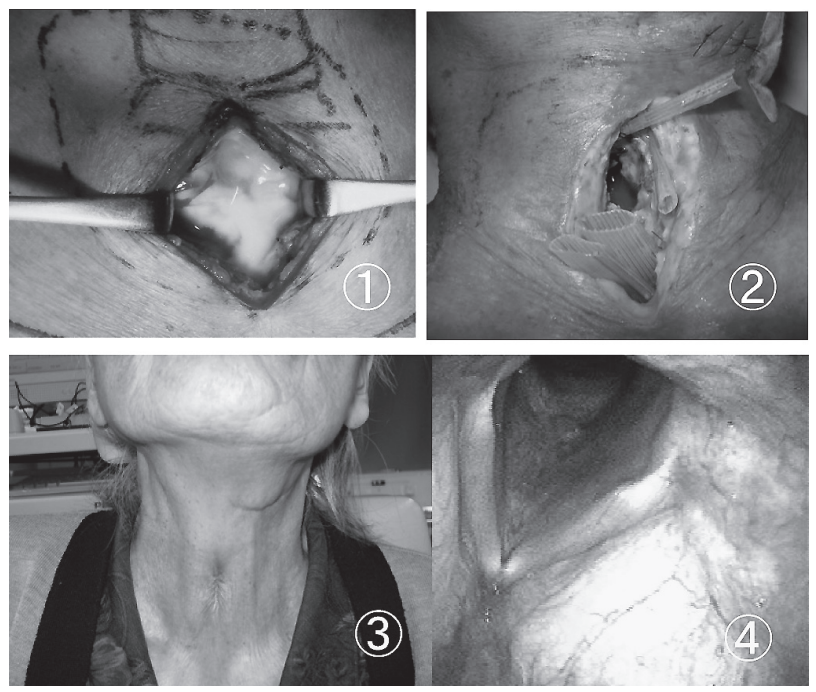

図 7 切開孔を閉鎖した頸部膿瘍症例

(1) : 前頸部の広範な膿瘍形成.

(2)：輪状軟骨開空術とドレーン留置

(3): 切開孔閉鎖後の頸部.

(4) : 肉芽・狭窄のない声門下閉鎖部.

炎など出血傾向の問題であった。骨転移・頸椎術後の頸部 伸展不能な状態で急激な喉頭浮腫を来した症例は輪状甲状 靶帯穿刺で気道確保した後, 続いて輪状軟骨開密術を行っ た。

\section{2. 輪状軟骨切開孔の閉鎖症例}

術後、切開孔閉鎖を行った症例は 57 例中 6 例であった。 長期切開孔管理が必要と判断された短頸・喉頭低位の 1 例 はCOPDが改善したため切開孔を閉鎖した。切開孔閉鎖が 可能と判断されていた上気道狭窄 6 例中 5 例は閉鎖できた が, 頸椎術後に頸部伸展不能の症例は術後, 肺癌からの肺 出血を繰り返し閉鎖することなく死亡した.

\section{3．輪状軟骨開空術の合併症}

術中、出血はわずかで止血に難渋する血管損傷はなく、 また気道確保が間に合わず窒息・低酸素脳症に至った症例 もなかった，術後、早期の合併症として，気管狭窄で気管 内挿管されていた短頸の 89 才女性の 1 例に, 切開孔周囲 に皮下気腫が認められたが縦隔気腫には至らず経過観察で 対処できた。 また出血傾向の症例でも止血術を要する術後 出血はなかった，気管カニューレに伴う合併症である自己 抜去や予期せ娧落による窒息事故もなかった。一方、カ ニューレの先端付近の気管に乾燥した痰が付着し、酸素飽 和度が低下した症例が数例あり、カニューレ先端と気管の 位置確認や加湿の不足が原因であった。

晚期の合併症である止血や切除を要する切開孔の肉芽・ 瘕痕形成はなく，カニューレ交換での挿入困難や出血はな かった，術後、長期間気管カニューレが留置された症例で も肉芽・㓔痕や狭窄の合併症で苦慮したものはなく, 肥満 


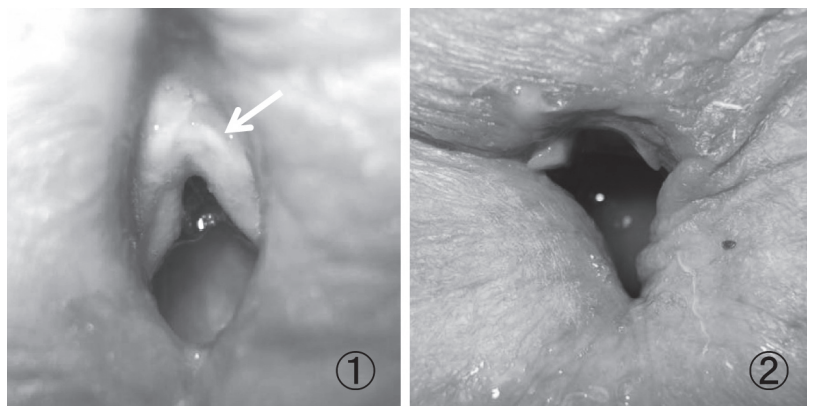

図 8 気管カニューレ長期留置例の切開孔

(1): 術後 2 年 2 ケ月. 肥満症例。切開孔上縁の譬状の 皮膚 $(\rightarrow)$.

肉芽や気管狭窄はない.

(2): 術後 8 ケ月. 上縁に圧迫痕はあるが, 肉芽の形成 は認めず。

や喉頭低位のような深い切開孔においても孔上部の皮膚に カニューレ湾曲部の圧迫による璧が形成されるものはあっ たが、気管内に肉芽・㓔痕による狭窄を形成したものはな かった（図 8)。一方，切開孔を閉鎖した 6 例の長期経過で も、声門下の切開部に肉芽・瘏痕の形成は認めなかった (図 7).

\section{考察}

\section{1. 輪状軟骨開空術の利点と適応}

気道確保術としての気管切開術は現在では確立した術式 として日常的に施行されているが，手術に伴う合併症は術 中・術後，早期・晚期で多岐にわたる，以前より，合併症 の発生原因や対策についての検討が多く報告 ${ }^{7 \sim 10)}$ されて いるが，いまた，症例の状態によってはその発生頻度は高 く，重大な合併症やトラブルにつながるのが現状である。

われわれは，2006 年，長期気管孔管理を要する高度の 肥満・短頸に対して気管切開術を依頼され，通常の気管切 開術で臨んだが，気管到達が困難で出血の危険性もあり， その場の判断で輪状軟骨を意図的に針除し切開孔を形成す る術式を行った。その後, 喉頭低位, 肥満・短頸, 頸部拘 縮伸展困難，腕頭・総頸動脈蛇行症、頭頸部癌末期の症例 や超緊急の上気道狭窄症例などに施行したが, 術中・術後 とも重篤な合併症の発生はなく，ハイリスクや長期カ ニューレ留置症例に打いて, 本術式は合併症を積極的に回 避する可能性があることがわかった ${ }^{11)}$ 。今回，その利点 を活かした本術式の適応について考察した。

1）超緊急症例に対する利点と適応

上気道狭窄が急激に増悪し超緊急での気道確保が必要に なる時に選択されるのが，皮膚から最も近く部位が同定し やすい輪状甲状靯帯の穿刺や切開術であり, 専用の医療器 材が診療現場でも準備されている。しかし，谷ら ${ }^{12)}$ は輪 状甲状鞁帯穿刺術の誤挿入により両側声帯麻痺の後遺症を 来した症例を報告し，誤挿入が稀なことではなく，最悪， 気道確保できない危険性も高いと認識しておく必要があ
る。肥満, 放射線治療や㓔痕で頸部皮膚が硬くなっている など頸部に異常のある症例では穿刺部を瞬時に同定するこ とは極めて困難でリスクが高い。また，輪状甲状鞀帯には 小さな切開孔しか開けることができず，太いカフ付き気管 カニューレの挿入は不可である.

輪状軟骨開密術は輪状甲状靱帯穿刺・切開術に比べ，大 きく切開し術野が広いため, 軟骨の触知は確実で, さらに 白線の同定も容易であり正中を誤ることなく目標の輪状軟 骨に到達できる。またこの術野では輪状甲状靯帯も明視下 になるため，手術途中で気道閉塞をきたし窒息の危機に 陥った時でも, 瞬時に輪状甲状鞁帯穿刺・切開術に逃げる ことができる，逆に輪状甲状勒帯穿刺・切開術に難渋した 場合, 広く切開を加えて輪状軟骨開空術に変更することは 窮状を回避する手段ともなる。

輪状甲状靱帯穿刺・切開術後の長期カニューレ留置は高 率に肉芽・瘏痕を形成するため避ける必要がある ${ }^{13)}$ 。そ のため, 穿刺 ·切開後は可及的早期に通常の気管切開術を 行うべき ${ }^{14)}$ とされているが，穿刺切開部位と連続する術 野で施行できる輪状軟骨開密術は長期気道管理が必要な症 例では肉芽防止の利点からも良い適応である。

2) 長期切開孔管理症例に対する利点と適応

気道狭窄が永久的な疾患や吸痰など気道管理が目的とな る症例では気管孔は長期間開存し, 気管カニューレに起因 する肉芽や痒痕による出血や狭窄などの合併症が問題とな り,さらに喉頭・気管狭窄, 気管カニューレ抜去困難症な ど重大な後遺症を来す原因となることが報告されてき た ${ }^{7 \sim 10,15)}$

気管カニューレ抜去困難症につながる肉芽・狭窄形成に ついて，気管孔の上縁にできることが多いこと ${ }^{15)}$, 高位 気管切開での輪状軟骨の接触・損傷でできることが報 告 $8,16,17)$ されている，その成因については気管孔上縁での カニューレの接触・圧迫による輪状軟骨の軟骨膜炎 ${ }^{15)}$, カニューレ長期留置による輪状軟骨壊死 ${ }^{17)}$, 高位に挿入 されたカニューレの鱟下運動での輪状軟骨の内腔粘膜壞

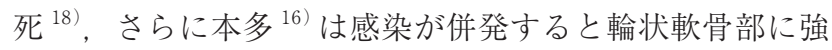
い痏痕形成が起こり最終的には輪状軟骨自体の吸収が起こ ることを報告している，そのため，現在まで成因に強く関 係する輪状軟骨を損傷・切開することや近接する第 1 気管 輪を切開する高位気管切開は避けるべき術式として広く認 識されてきた。しかし, 長期切開孔管理を要する症例には 喉頭低位, 肥満・短頸, 頸部拘縮, 頸部伸展困難など高位 気管切開術を選択せざるを得ないものも少なくない.

一方，喉頭低位や肥満・短頸に対して無理に通常の気管 切開をすると、気管孔は縦隔側に深く形成され, 結果的に 気管カニューレ彎曲部による第一気管輪や輪状軟骨への強 い圧迫は避けられず，長期経過ともに軟骨が容易に壊死・ 変形し, 高位気管切開術を避けたとしても高度の肉芽・瘏 痕・狭窄の形成が推測される。

輪状軟骨開空術は肉芽・瘏痕の成因となる輪状軟骨その ものを鉗除する術式であり，喉頭低位や肥満・短頸でも肉 
芽・㾮痕防止に効果的と考えられ，蠇崎ら ${ }^{3)}$ や平位ら ${ }^{6)}$ の 報告でも喉頭低位や肥満で肉芽・瘏痕形成した症例はな かった。今回報告した 57 例中，切開孔を開存して管理さ れた 51 例では切開孔上縁にカニューレの圧迫による皮膚 の璧形成はみられたが，切開孔周囲，声門下腔や気管内に 狭窄の原因となる肉芽・痏痕の形成は認めなかった。

輪状軟骨を意図的に鉗除・操作することは肉芽・㓔痕や 狭窄のリスクとならないだけでなく，それ以上に発生防止 に寄与することがわかり，本術式は長期切開孔管理を必要 とする症例では積極的な適応を有し，選択を考慮すべき術 式であると考えられた。

3) 頸部異常の症例に対する利点と適応

気管切開術は日常的に施行される手術であるが、頸部の 状態によって、手術の難易度や術後の合併症のリスクが大 きく異なるのが特徴の術式でもある。輪状軟骨の位置が胸 鎖関節の直上まで下がっている喉頭低位の症例は中気管切 開術の難易度は高く、術後の気管孔は深く縦隔に近接する ため, カニューレ挿入時のトラブルや出血や縦隔気腫など 合併症は重篤化しやすい。 また, 島田ら ${ }^{19)}$ は高度の肥満 で気道への到達が難しく合併症が危惧された症例を報告し ているが、長期管理ではさらに合併症の発生リスクが増す ことが推察される。

腕頭・総頸動脈蛇行症も切開部が問題となる. 甲状腺峡 部切離に伴うリスクから、中気管切開ができず高位気管切 開術を行った報告 ${ }^{20)}$ もる。 また, 甲状腺腫瘍や慢性甲 状腺炎など甲状腺峡部が腫大を来している症例の気管切開 でも切開部の露出に難渋し手術の難易度は高くならざるを 得ない．特に未分化癌では気管到達も困難で峡部切開時に 大量出血の危険性があり, 特別な処理・操作が必要とされ $3^{16)}$.

総頚・腕頭動脈蛇行症例に対して, 堀ら ${ }^{5)}$ や平位ら ${ }^{6)}$ は 輪状軟骨開密術を施行し動脈から離れた部位を切開する本 術式の安全性を、蠣崎ら ${ }^{3)}$ や酒井ら ${ }^{4)}$ は甲状腺腫瘍の理由 による輪状軟骨開空術を報告している。当科では喉頭低 位, 肥満・短頸から本術式を選択したものが多かったが, 頸部膿瘍，腕頭 - 総頸動脈蛇行症，未分化癌を含む甲状腺 腫瘍, 食道癌甲状腺浸潤, 頸部膿瘍など気管切開部に問題 があった症例も適応とした。

喉頭レベルに切開孔を形成する輪状軟骨開空術は皮膚か ら軟骨までが最も近いため、喉頭低位, 肥満・短頸の頸部 異常に対して有利である。また，甲状腺峡部に操作を加え ず頭側に切開孔形成できることから気管切開部に問題のあ る症例にとっても第一選択となりうる術式であることがわ かった。

4）出血傾向の症例に対する利点と適応

気管切開術の術中・術後の重要な合併症のひとつが出血 である，その原因として甲状腺との関連を挙げる報告は多 ( $^{7,10,21)}$. 甲状腺には多くの血管が存在し, その走行にも バリエーションがある，通常の気管切開術の術野には甲状 腺下縁から縦隔に向かう複数の最下甲状腺静脈が現れ，下
甲状腺動脈の分枝も存在する。上縁には上甲状腺動脈の分 枝と静脈が走行する。 甲状腺自体も血行に富み，中気管切 開では甲状腺峡部の切離に甲状腺下縁の血管処理が必要と なる，喉頭低位や肥満の例では甲状腺下縁はより梁い操作 となり，視野を確保しようと喉頭を率引することにより， 局所麻酔や呼吸苦を訴える症例では体動や嚥下を誘発し, 血管損傷のリスクが著しく高まる。こうした状況が高位気 管切開術を選択させてしまう一因となっていると推察され る.

竹澤ら ${ }^{22)}$ は高度肥満に加えて血友病を合併する出血傾 向の治療経験を報告している. 須長ら ${ }^{9)}$ は出血素因のある 症例の術後出血の頻度が高いこと, また, 他科依頼の気管 切開術では出血素因のある症例を多く施行する傾向があ り, 術後出血の危険性が高いと報告している. さらに近年, 虚血性心疾患, 心房細動などで抗血栓剂を処方される患者 数は社会の高齢化に伴い激増しており，寝たきり症例での 使用頻度も低くない.こうした症例では休薬期間がとれな いまま緊急の気管切開術となるため, 出血のリスクが高く 成らざるを得ない.

輪状軟骨開空術は, 甲状腺の操作を回避でき, 血管の走 行の疎らな輪状軟骨周囲のみで操作が済むため安全な術式 といえる。また術後に出血をきたした場合でも止血操作は 浅い位置で対応できる，今回の症例にも，ワルファリンカ リウム内服中に咽喉頭粘膜から頸部皮下まで広範な出血を 来していたものがあったが，安全に行うことができた．

5) 気管カニューレ事故に対する利点と適応

気管切開術の術後早期に気管カニューレを抜去すると短 時間で気管孔は狭くなり, さらに皮膚切開部と気管孔のず れや気管軟骨の断端の張り出しでカニューレの再挿入が困 難になる。こうした状態での無理な挿入操作は気管を外れ た誤挿入につながり，窒息，縦隔気腫など死亡事故につな がる $^{7,10)}$. 不穏・多動, 小览や人工呼吸器使用の症例は気 管カニューレの自己抜去や脱落のハイリスク症例としてよ り注意深い管理が必要である。

今回の治療経験をみると, 輪状軟骨が鉗除された切開孔 は気管切開孔とは異なり, カニューレが抜去されても短時 間に縮小しないことがわかった。そのため喉頭低位や肥 満・短頸など頸部の形態異常の症例でもカニューレの交換 や再挿入は慌てることなく安全に行うことができた。本術 式は不穏・多動, 長期の人工呼吸器使用症例にも選択され たが, 窒息, カニューレ誤挿入などの事故はなく, 医療事 故回避にも有用であると考えられた。

気管切開術の合併症はその多くが気管カニューレに起因 するが，その中でも気管壁損傷による気管腕頭動脈瘦は致 命的になる。そのカニューレ先端の位置の対策 ${ }^{7,23}$ もある が, 根本的にはカニューレなしでの管理が望まれる ${ }^{23)}$. 輪状軟骨開空術はカニューレ先端の位置を通常の気管切開 よりも上方にできる利点がある。また今回, 輪状軟骨の鉗 除に加えて第 1 や第 2 気管輪も切開し広く形成した症例の 中に, カニューレ留置なしでも狭窄せず開存のまま維持で 
きた症例（図 4）があり，本術式は意図的にカニューレフ リーの永久気管孔を形成でき, カニューレ先端による致死 的な合併症回避の有用な術式となることが示唆された。

\section{2. 外科的気道確保術の術式分類と選択のフローチャート}

気道確保の外科的方法は気道に到達する位置により, 輪 状甲状靯帯を通過する方法としての輪状甲状靸帯切開術と 輪状甲状靯帯穿刺術と気管壁を通過する方法としての上 · 中・下気管切開術に分類されている ${ }^{24)}$ 。術式の選択は、 現状では超緊急症例に対する輪状甲状勒帯穿刺・切開術と 超緊急以外の気管切開術に分けられるだけであった。近 年, 高齢化社会の中で長期の気道管理や抗血栓剤内服症例 に対する気道確保術の依頼が増加していることに加えて, 医療事故に厳しい臨床現場に扔いてはより安全な気道確保 術が必要とされている.

今回、報告した術式は輪状軟骨レベルの声門下に気道が 開空される、これまでの術式の通過する部位とは異なる特 異なものであり, 今回, その特徴を現す「輪状軟骨開空術」 の名称で報告し,「Cricoid Fenestration」を英語訳として 表記した。

本術式は安全をより重視する気道確保術となり得ること を報告したが，その利点を活かした術式選択について，緊 急性，長期気管孔管理，頸部異常や出血傾向の有無を条件 としたフローチャートを呈示した（図 9). 個々の症例の状 態・状況, 適応理由, リスクの程度を判断し, このフロー チャートに沿って術式を術前に的確に選択して手術に臨む ことは, 気道確保術の安全性向上のための重要なポイント になる．

最後に, 気道確保術は臨床現場では他科の医師が施行 し，合併症に苦慮しているケースは少なくない，そうした 場において、気道管理の専門である耳鼻咽喉科医はより安 全で具体的な方法を指導・啓蒙することが責務である，本

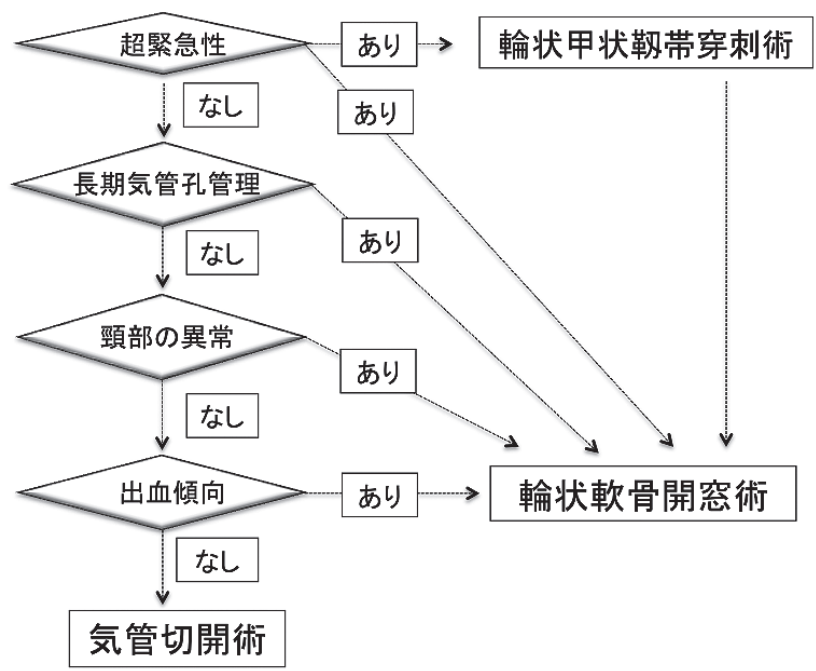

図 9 気道確保術の術式選択フローチャート
術式がその具体的な方法のひとつとして手術書に記載され 周知されることを期待する.

$$
\text { ま と め }
$$

1. 輪状軟骨開密術を施行した 57 例の治療成績を報告し た。

2. 本術式は意図的に輪状軟骨を鈿除し喉頭レベルに開空 する新しい気道確保術である。その特徴は甲状腺に操 作を加えることなく，高い位置に切開孔を形成できる ことである。本術式は超緊急，長期切開孔管理，頸部 異常や出血傾向のハイリスク症例に対して合併症防止 に有用であり，また気管カニューレによる医療事故の 回避にも寄与する安全性の高い気道確保術であること がわかった。

3. 輪状軟骨開空術は，八イリスク症例に対する安全性向 上のための外科的気道確保術の有用な選択肢のひとつ となる。

利益相反に該当する事項はない．

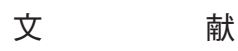

1）鹿野真人：耳鼻咽喉科医の立場から-長期臥床患者に 対する気管切開とその管理一。第 17 回日本気管食道 科学会認定気管食道科専門医大会テキスト：35-39, 2007.

2）鹿野真人：輪状軟骨鉗除を併用する気管切開術の術後 経過. 日気食会報 $60: 169,2009$.

3）蠣崎文彦, 津布久崇, 対馬那由多ほ力：輪状軟骨鉗除 による気管孔形成術の検討。頭頸部外科 $22: 87-92$, 2012.

4）酒井明博, 大上研二, 杉本良介ほか：輪状軟骨鉗除に よる気管孔形成術。日気食会報 $60: 169,2009$ ，

5）堀 健志, 廣瀬敬信, 原 浩貴汸: 右総頚動脈蛇行 症に対して高位気管切開術を施行した 1 例。日気食会 報 $65: 50-53,2014$.

6）平位知久, 福島典之, 鹿野真人ほか：輪状軟骨を鉗除 する喉頭気管手術。日耳鼻 $118: 1233-1240,2015$.

7）平林秀樹 : 気管切開の合併症. 日気食会報 58 : 463471, 2007.

8）山田弘之, 宮村朋孝, 福家智仁ほか：気管切開に伴う 合併症への対応と回避。日気食会報 $57: 458-463$, 2006.

9）須長 寛, 藤枝重治: 通常の気管切開術の適応, 手技, 早期合併症。日気食会報 $59: 172-177,2008$.

10）二藤隆春, 肥後隆三郎：気管切開術におけるトラブル の予防と対応. JOHNS 19:440-444, 2003.

11）鹿野真人：気管切開術後の管理 - 合併症とその対策· 予防一。 JOHNS 29:1715-1720, 2013.

12）谷 亜希子, 多田靖宏, 小野美穂ほか：輪状甲状鞁帯 
穿刺部の誤りにより声帯麻痺を生じた 1 例。日気食会 報 $65: 464-467,2014$ 。

13）谷亜希子, 田勢長一郎, 多田靖宏ほか：当院で施行 された輪状甲状靫带穿刺の解析. 日気食会報 66 ： 191-197, 2006.

14）北野博也：気管切開術。日気食会報 $58: 433-439$, 2007.

15）廣戸幾一郎：気管切開による後障害. 日医事新報 2398: 12-15, 1970 .

16）本多芳男：気管切開の後遺症耳展 $12: 279-288$, 1969.

17）石田良治, 山田弘之, 西井真一郎ほか：高位気管切開 に伴うカニューレ抜去困難症の治療。日気食会 報 $54: 219-222,2003$.

18）箕山 学, 田辺正博, 田中信三：輪状軟骨部分壊死を 伴った声門下狭窄の治療。日気食会報 49：451-457， 1998.
19）島田剛敏，山本 聡，四ノ宮 隆ほか：高度肥満患者 に対する気管切開術。 日耳鼻 $107: 319-323,2004$.

20）堀容子, 橋本 省, 香取幸夫ほか：腕頭動脈蛇行症 に打ける気管切開術。日耳鼻 $107: 152-155,2004$.

21）内海重光, 佐藤武男, 中島礼士ほか: 気管切開とその 後障害。日気食会報 21 (補)：12-19, 1970 .

22）竹澤公美子, 柴山将之, 神前英明潘: 高度肥満, 血 友病 A, HIV ・ HCV 感染症のある患者に対する気管 切開術。日気食会報 $65: 54-60,2014$.

23）森 照茂，箕山 学，柿木裕史ほか：気管腕頭動脈瘻 の 1 例。日気食会報 $57: 516-520,2006$.

24）丸山征四郎：各気管切開法の概要. 気管切開 - 外科的 気道確保のすべてー, (丸山征四郎編). 2-3, 医学図 書出版, 東京, 2002 .

別刷請求先 ₹ 960-8611 福島県福島市大町 6-11 大原綜合病院耳鼻咽喉科・頭頸部顔面外科 鹿野真人 